DOI: http://dx.doi.org/10.33846/hn31002

http://heanoti.com/index.php/hn

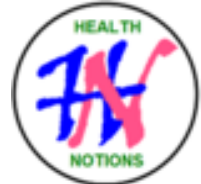

RESEARCH ARTICLE

URL of this article: http://heanoti.com/index.php/hn/article/view/hn31002

\title{
The Relationship Between Mother Visit to Maternal and Child Health Centre (MCHC) and Timely of Giving Complementary Foods in Timur Tengah Selatan Regency, Nusa Tenggara Timur Province
}

\author{
Wenny I. Ischak ${ }^{1(\mathrm{CA})}$ \\ ${ }^{1(\mathrm{CA})}$ Department of Nursing, Health Polytechnic of Gorontalo, Indonesia; wennyischak@ymail.com \\ (Corresponding Author)
}

\begin{abstract}
The introduction of feasible complementary foods at 6 months together with continued breastfeeding up to two years of age or beyond. is very important to infant. This study aimed to assess factors associated with the accuracy of the age of supplementary feeding to infant. This study used a cross-sectional design of communitybased and carried out in nine districts in the Timur Tengah Selatan Regency,Nusa Tenggara Timur province. It was conducted of the month, October to December 2013 in 9 sub-districts selected. The research subjects were children aged 6-23 months $(\mathrm{n}=3578)$. Data were collected by trained local personnel using a standardized questionnaire. This study showed that there is $77.4 \%$ of the respondents have given complementary feeding at suggested time (6 mounths). Type supplementary food given was $56.5 \%$ in the form of instant porridge. Giving of complementary foods at 6 months as recommended midwife was 34.6\% whereas the reason that it was time to give complementary food before the age of 6 months was only 7.9\%. it was found statistically significant where the correlation between giving complementary foods and regularly bring the child to the IHC was $93.7 \%$ $(P=0: 02)$, while its relationship with the child's diet counseling ever got was $78.5 \%(P=0.00)$.
\end{abstract}

Keywords: complementary foods; integrated health care; children 6-24 mounths of age

\section{INTRODUCTION}

\section{Background}

Infants and young children were vulnerable to malnutrition from the age of six months onwards, When breast milk is no longer enough to meet the nutritional needs of the infant, complementary foods should be added to the diet of the child. Breastfeeding should be continued up to two years or more and appropriate complementary food such as nutritious, safe, and the right type to be introduced at the age of six months to meet the needs of children's growth.

At the age of 6 months, babies of normal weight had reached 2-3 times the baby's weight at birth. The rapid growth needs to be accompanied by the supply of calories and adequate nutrition. Therefore, in addition to breastmilk, infants at the age of 6 months should be given additional food that adapted to baby's stomach's ability to digest food.

Complementary feeding with breastfeeding up to 2 years old baby is very important for infants ${ }^{(1)}$. In children aged 6-24 months, especially infants, weight curve is very important to know. Weight children aged 624 months down easily both in physical and psychosocial aspects in the event of a nutrition crisis. To improve the nutritional and health status of the child through appropriate feeding practices ${ }^{(2)}$. Through complementary feeding and other food additives are also adequate zinc and iron, as well as energy-dense, micronutrient can be provided for children's growth and their brain development. 
Complementary feeding, if not done properly, can be followed by diarrhea and growth retardation leading to kwashiorkor, marasmus and immunodeficiency characterized by recurrent and persistent infections that could be fatal ${ }^{(3)}$. Inadequate intake of food/nutrition is a major factor for malnutrition. Malnutrition causes babies were underweight ${ }^{(4)}$.

Proper breastfeeding and complementary feeding practices can prevent infant mortality by $19 \%{ }^{(5)}$. In Indonesia, a child is very risky died when he was suffering from severe malnutrition. Each year 150,000 children die before reaching the age of 5 years, especially among the poor ${ }^{(6)}$.

Appropriate complementary feeding depends on accurate information and proficient support from the family, the community and the health system. Adequate knowledge of the practices and eating the right foods is often the major determinant of malnutrition than the lack of food. Mothers' knowledge of these factors will greatly help in planning to improve feeding practices. In addition, maternal education were influence on feeding the family. Mother's education is the dominant factor in the provision of food, low education is associated with a never breastfed and did not follow the correct feeding guidelines for children.

Investigated the factors associated with the provision of complementary feeding in Indonesia and showed that infants from poor families were significantly less likely to introduce complementary foods. In addition, when children over 2 years of age are not met well food intake until reaching the age of 5 years, the fulfillment of which are less nutrients can affect growth and development ${ }^{(2)}$.

\section{Objective}

This study was conducted to determine the practice of supplementary feeding in children the age of six months to two years. The results of this study will assist in educating mothers on complementary feeding.

\section{METHODS}

The type of this research is descriptive analytic and used a community-based cross sectional design and carried out in nine districts around Timur Tengah Selatan Regency, Nusa Tenggara Timur province. This research was conducted for three months from October 2013 to December 2013. The population in this study were all parents (mothers) or caregivers of children aged 6-23 months who were in the Timur Tengah Selatan Regency. The sampling technique used was purposive sampling, with a total sample of 3600 respondents. The independent variables are social demography, mother's knowledge, and mother's perspective, while the dependent variable is complementary feeding.

Inclusion criteria for this study were the parents (mother) or caregivers of children aged six months to twenty-three months who live or lived in the region. 3600 children were observed as a target respondents in this study. For children who are known have a problematic disorder of malnutrition (kwashiorkor/marasmus) and severe certain diseases were not used as a respondent.

Data collectors were trained before the gathering of data. Age group subjects were selected based on the recommendations of WHO on complementary feeding is initiated from children aged 6 months. Subjects met door-to-door according to their willingness during the study period. Data were collected using a structured questionnaire was given to the mother.

The questionnaire includes information on the demographic profile, breastfeeding and complementary feeding. Socioeconomic status was calculated based on expenses for food and non-food for a month and categorized based on the minimum regional payment where research was conducted. Education of respondents are categorized by the policy/government rules of compulsory nine years.

Data processing was performed using SPSS software version 17.0 to describe the frequency distribution of the data and identify the correlation between socio-demographic variables factor with the initial of complementary feeding and a positive attitude toward complementary foods used Chi-square statistical test with a p-value $<0.05$ level of significance.

\section{RESULTS}

Based on the overall target of respondents (3600), a total of 3578 agreed to participate in the study, or $99 \%$. Some of the reasons given by the mother or caregiver to not participate in this study was the lack of time and object to participate in this study. From 3578, the majority of children in $1638(45.7 \%)$ included in the age group from 6 to 11 months, 1913 (53.5\%) were male. Most mothers / caregivers that $2815(78.7 \%)$ were housewives, and of education 0-9 years in 2560 (70.8\%) As shown in the table 1 below. 
Table 1. Social demographic characteristic of respondents

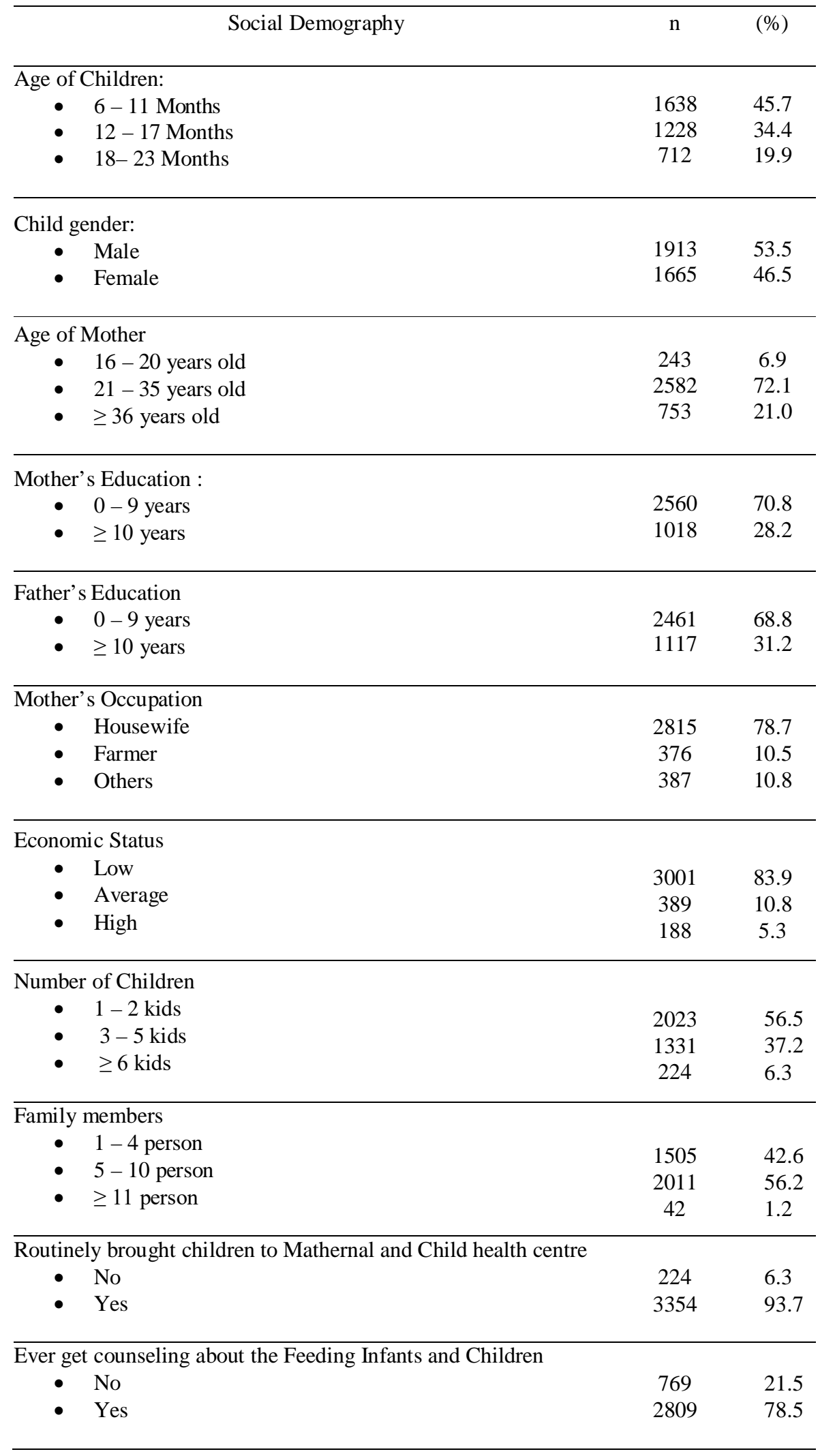


Mother's knowledge about the purpose of the first 1,000 days of life most of 3439 (96.1\%) did not know, knowledge of signs and symptoms of malnourished children only 1448 (40.5\%) who knows. As shown in the Table 2.

Table 2. Mother's knowledge about breastfeeding dan complementary feeding

\begin{tabular}{lcc}
\hline \multicolumn{1}{c}{ Statement } & $\mathrm{n}$ & $(\%)$ \\
\hline $\begin{array}{l}\text { Did you know about the first 1,000 days of life? } \\
\text { - No }\end{array}$ & 3439 & 96.1 \\
- Yes & 139 & 3.9 \\
& & \\
\hline Is allowed provide food and beverages whether children can use & & \\
bottles and nipples? & 2508 & 70.1 \\
- No & 1070 & 29.9 \\
• Yes & & \\
\hline$\quad$ No & 2130 & 59.5 \\
\hline Did you know the signs and symptoms of child malnutrition ? & 1448 & 40.5 \\
- & &
\end{tabular}

Did you know that a child's needs over 2 years compared with

children aged 6-24 months should be fewer in number.

- No

$2425 \quad 67.8$

- Yes

$1153 \quad 32.2$

Did you know that eating need for children over 2 years

compared with children aged 6-24 months should be more varied

diet.

- No

$1734 \quad 49.5$

- Yes

$1769 \quad 50.5$

Majority of respondents (79.9\%) agree on the perspective of the mother does not need to provide other foods before the age of 6 months as well as who agreed by giving complementary foods are varied not only rice porridge but also added vegetables, fish and eggs reaching $84.3 \%$.

Most respondents $(70.1 \%)$ are still in the status of breastfeeding. For who exclusive breastfeeding or not providing food and drink before the age of 6 months were $71.4 \%$ and respondents who give colostrum or yellowish breastmilk were $92.9 \%$.By the overall population, $77.4 \%$ of mothers had started providing complementary foods at the recomended time (children aged 6 months) and only $22.6 \%$ had given complementary foods before it. 
Table 3. Perpectives on complementary feeding

\begin{tabular}{|c|c|c|c|c|c|}
\hline \multirow[t]{2}{*}{ Perspectives } & \multicolumn{5}{|c|}{ Statement } \\
\hline & $\begin{array}{l}\text { Very } \\
\text { Disagree }\end{array}$ & Disagree & Not Sure & Agree & Very Agree \\
\hline $\begin{array}{l}\text { Before the 6-month- } \\
\text { old child does not need } \\
\text { to get food other than } \\
\text { breast milk }\end{array}$ & $\begin{array}{c}11 \\
(0.3)\end{array}$ & $\begin{array}{l}165 \\
(4.6)\end{array}$ & $\begin{array}{l}117 \\
(3.2)\end{array}$ & $\begin{array}{l}2890 \\
(79.9)\end{array}$ & $\begin{array}{c}395 \\
(10.9)\end{array}$ \\
\hline $\begin{array}{l}\text { Children aged } 4 \\
\text { months are frequent } \\
\text { crying, should be given } \\
\text { food like bananas and } \\
\text { porridge }\end{array}$ & $\begin{array}{l}128 \\
(3.5)\end{array}$ & $\begin{array}{l}1929 \\
(53.4)\end{array}$ & $\begin{array}{l}243 \\
(6.7)\end{array}$ & $\begin{array}{l}1247 \\
(34.5)\end{array}$ & $\begin{array}{l}31 \\
(9)\end{array}$ \\
\hline $\begin{array}{l}\text { Complementary feeding } \\
\text { can be given before the } \\
\text { age of } 6 \text { months if the } \\
\text { child does not want to } \\
\text { be breastfed }\end{array}$ & $\begin{array}{c}96 \\
(2.7)\end{array}$ & $\begin{array}{r}1485 \\
(41.1)\end{array}$ & $\begin{array}{l}366 \\
(10.1)\end{array}$ & $\begin{array}{l}1583 \\
(43.8)\end{array}$ & $\begin{array}{c}43 \\
(1.2)\end{array}$ \\
\hline $\begin{array}{l}\text { Complementary feeding } \\
\text { should be given varies } \\
\text { added vegetables, fish, } \\
\text { eggs, not only rice } \\
\text { porridge }\end{array}$ & $\begin{array}{c}14 \\
(0.4)\end{array}$ & $\begin{array}{l}132 \\
(3.7)\end{array}$ & $\begin{array}{l}177 \\
(4.9)\end{array}$ & $\begin{array}{l}3017 \\
(84.3)\end{array}$ & $\begin{array}{r}238 \\
(6.7)\end{array}$ \\
\hline
\end{tabular}

The reason to provide additional food becaused of recommended by midwives were $34.6 \%$ and $14.4 \%$ of respondents had other reasons such as social habits, recommended by relatives, neighbors and do not know. Type of complementary foods given most of instant porridge were $56.5 \%$ and 15:25\% such as, milk porridge, biscuits, eggs and fruit. Breastfeeding yellowish (colostrum) were $92.9 \%$ and $70.1 \%$ children were still in breastfed. 
Table 4. Breastfeeding practices and provision complementary food

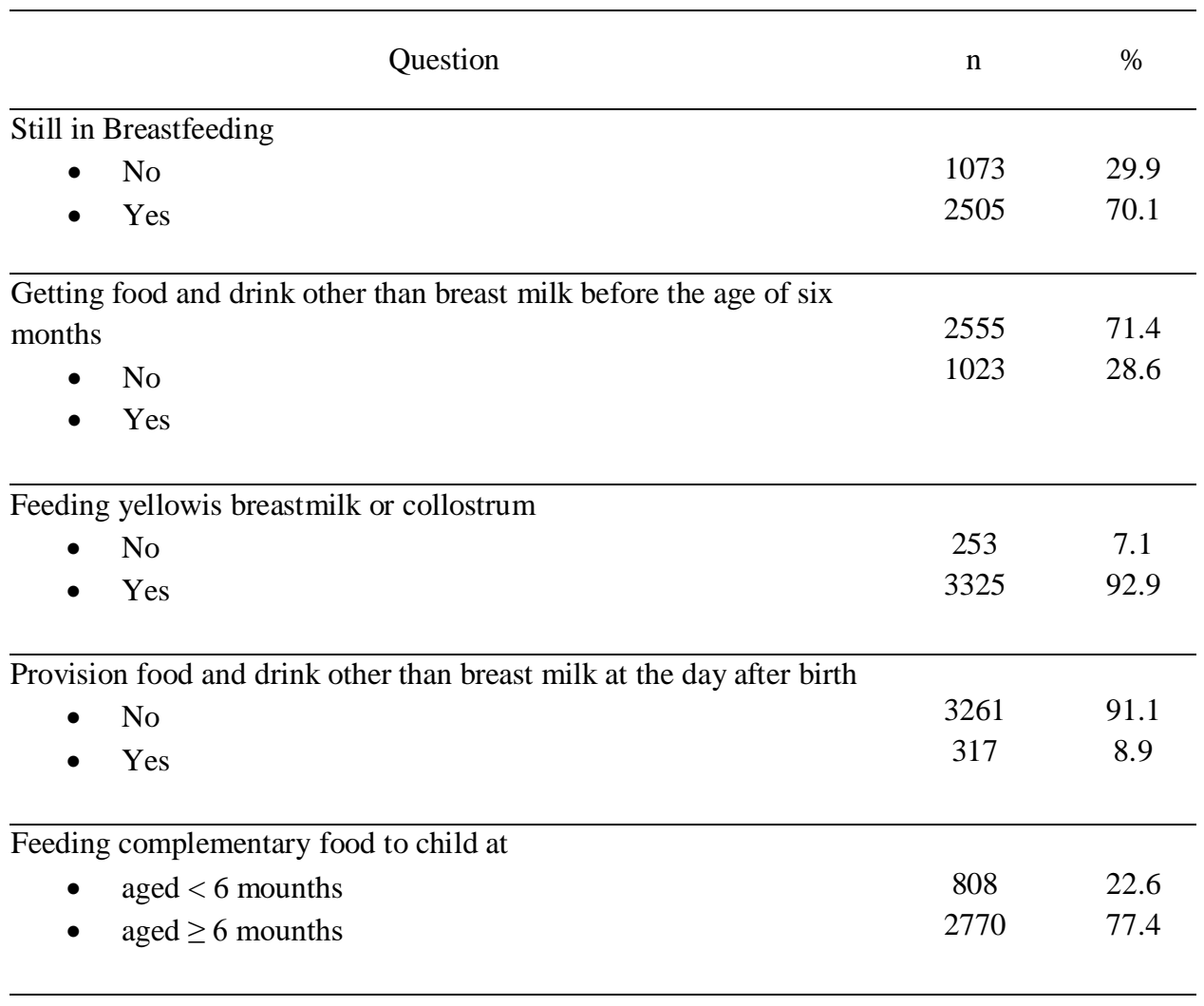

The reason to feed complementary food at the age:

- Recommended by midwives

- Own mother wishes

$757 \quad 21.1$

- Child were hungry

$570 \quad 15.9$

- It's time to give complementary foods

$283 \quad 7.9$

- Family habit

$216 \quad 6.0$

- Habit

$512 \quad 14.4$

Types of food that given at first time

- Instant porridge

$2025 \quad 56.5$

- Filtered porridge

- Banana

186

5.1

- Rice-porridge

147

5.1

- Mil-porridge

- Others

Provision food but breastmilk in the last 24 hours

- No

$134 \quad 3.7$

- Yes

$3444 \quad 96.3$

Mother wash her hands with clean water, soap and water before giving food to children
- No
921
25.7
- Sometimes
$2006 \quad 56.1$
- Always

$651 \quad 18.2$


Based on the results of bivariate analysis using chi square test showed that the practice of providing supplementary food at the recommended time (aged 6 months) was significantly associated with regular mother brought the child to the neighborhood health center $(P=0.002)$ had received counseling about supplementary feeding $(P=0.000)$ and the number of family members $(\mathrm{p}=0.005)$. In contrast to the mother's age, education, occupation, number of children, child gender and socio-economic showed no correlation. As shown to the table.

Table 5. Factors associated with the provision of complementary feeding at the first time.

\begin{tabular}{|c|c|c|c|}
\hline \multirow{2}{*}{ Factors } & \multicolumn{2}{|c|}{$\begin{array}{l}\text { Provision of complementary } \\
\text { feeding at the first time }\end{array}$} & \multirow[t]{2}{*}{$\mathrm{P}$-value } \\
\hline & $<6$ months & $\geq 6$ months & \\
\hline $\begin{array}{l}\text { Mothers age } \\
\text { - } \quad 16-20 \text { years old } \\
\text { - } \quad 21-35 \text { years old } \\
\text { - } \quad \geq 36 \text { years old }\end{array}$ & $\begin{array}{l}70(28.8) \\
571(22.1) \\
167(22.2)\end{array}$ & $\begin{array}{l}173(71.2) \\
2011(77.9) \\
586(77.8)\end{array}$ & 0.056 \\
\hline $\begin{array}{c}\text { Mother's education } \\
\bullet \quad 0-9 \text { years } \\
\bullet \quad \geq 10 \text { years }\end{array}$ & $\begin{array}{l}577(22.5) \\
231(22.7)\end{array}$ & $\begin{array}{l}1983(77.5) \\
787(77.3)\end{array}$ & 0.922 \\
\hline $\begin{array}{c}\text { Father's education } \\
-\quad 0-9 \text { years } \\
\text { - } \quad \geq 10 \text { years }\end{array}$ & $\begin{array}{l}562(22.8) \\
246(20.0)\end{array}$ & $\begin{array}{l}1899(77.2) \\
871(78.0)\end{array}$ & 0.590 \\
\hline $\begin{array}{l}\text { Mother's occupation } \\
\text { - Farmer } \\
\text { - Housewife } \\
\text { - Others }\end{array}$ & $\begin{array}{l}81(21.5) \\
625(22.2) \\
102(26.4)\end{array}$ & $\begin{array}{l}295(78.5) \\
2190(77.8) \\
285(73.6)\end{array}$ & 0.164 \\
\hline $\begin{array}{c}\text { Child gender } \\
\qquad \quad \text { Male } \\
\bullet \quad \text { Female }\end{array}$ & $\begin{array}{l}429(22.4) \\
379(22.8)\end{array}$ & $\begin{array}{l}1484(77.6) \\
1286(77.2)\end{array}$ & 0.810 \\
\hline $\begin{array}{c}\text { Number of Children } \\
\text { - } \quad 1-2 \text { kids } \\
\text { - } \quad 3-5 \text { kids } \\
\text { - } \quad \geq 6 \text { kids }\end{array}$ & $\begin{array}{l}469(23.2) \\
293(22.0) \\
46(20.5)\end{array}$ & $\begin{array}{l}1554(76.8) \\
1038(78.0) \\
178(178)\end{array}$ & 0.549 \\
\hline $\begin{array}{l}\text { Family members } \\
\text { - } 1-4 \text { person } \\
\text { - } \quad 5-10 \text { person } \\
\text { - } \quad \geq 11 \text { person }\end{array}$ & $\begin{array}{l}311(27.0) \\
471(23.4) \\
15(35.7)\end{array}$ & $\begin{array}{l}1194(79.3) \\
1540(76.6) \\
27 \quad(64.3)\end{array}$ & 0.005 \\
\hline $\begin{array}{l}\text { Routinely brought children to Mathernal and Child health } \\
\text { centre } \\
\text { - No } \\
\text { - Yes }\end{array}$ & $\begin{array}{l}68(308) \\
739(22.0)\end{array}$ & $\begin{array}{l}155(69.2) \\
2615(78.0)\end{array}$ & 0.002 \\
\hline $\begin{array}{l}\text { Ever get counseling about the Feeding Infants and Children } \\
\qquad \text { No } \\
-\quad \text { Yes }\end{array}$ & $\begin{array}{l}676(24.1) \\
141(18.3)\end{array}$ & $\begin{array}{l}2133(75.9) \\
628 \quad(81.7)\end{array}$ & 0.000 \\
\hline $\begin{array}{l}\text { Economic Status } \\
\text { - Low } \\
\text { - Average } \\
\text { - High }\end{array}$ & $\begin{array}{l}666(22.2) \\
94(24.2) \\
48(25.5)\end{array}$ & $\begin{array}{l}2335(77.8) \\
295(75.8) \\
140(74.5)\end{array}$ & 0.453 \\
\hline
\end{tabular}




\section{DISCUSSION}

In this study, the majority of mothers $(96.1 \%)$ did not know about the purpose of the first 1,000 days of life, and only $40.5 \%$ of respondents had no knowledge of the signs and symptoms of of childhood malnutrition. These results are supported by educational level of the mothers (70.8\%) were educated only 0-9 years. Increasing knowledge could be influencing the consciousness of the mother in caring their children's health ${ }^{(5)}$.

This study also showed that $79.9 \%$ of respondents agreed to not have to give other foods before the age of 6 months. Likewise, $84.3 \%$ of respondents agreed about mothers manner in giving complementary foods as varied as added vegetables, fish, eggs, and not just rice porridge. This result is supported by the knowledge of mothers about more varied food for children were $50.5 \%$ and the type of complementary foods was instant porridge at first given (56.5\%). These results are in line with the results Aggarwal et al., (2008) that the knowledge and manner to varied complementary foods significantly associated with mothers education (P $<0.05)^{(7)}$.

Education and extension aimed to improve the mother's knowledge. so hopefully the mother could understand the importance of food and nutrition, it will form the attitude and behavior change towards a better diet. The importance of attitudes and behaviors of mothers in complementary feeding for moderately malnourished children ${ }^{(8)}$. positive attitude of parents towards infant feeding is an important component in the nutritional health of children ${ }^{(9)}$.

Another aspect related to the mother's attitude regarding the provision of a varied diet in children is due to the economic status of the family. In this study, $83.9 \%$ of respondents are low economic status. Children who live in poor households are significantly less likely to meet the diversity of food ${ }^{(10)}$. Multivariate analysis in Tanzania that the main risk factors for complementary feeding practices that are not appropriate for children aged 6-11 months are poor economic status and low educational level ${ }^{(11)}$.

In this study, there were $77.4 \%$ of respondents giving complementary foods to children at the recommended age, the age of 6 months. These results are supported by a study of 200 women in southern India, where $77.5 \%$ of parents of children aged under two years had given appropriate complementary foods at recommended time ${ }^{(5)}$ and of the results of research Victor et al., (2012) which used multistage cluster sample of 10,000 households found the pervalensi introduction of complementary feeding $92 \%$ at age 6-8 months ${ }^{(11)}$.

Similar results also found from Chapagain (2013) used cross-sectional approach at 1100 mothers of children aged 6-24 months obtained more than half of the respondents $(56.81 \%)$ provide complementary foods according to the recommended time ${ }^{(12)}$. Lower results found in nutritional intervention study by Sethi et al., (2003) of the 35 parents in Delhi found only 16.5\% of parents giving complementary foods at the recommended time $^{(13)}$. This is likely due to differences in the number of samples used by each researcher. However, in contrast to the study by Adokiye, (2010) cross-sectional study with a mult-stage sampling of the 384 respondents indicated no association between early introduction of complementary foods for children before the age of 6 months with nutritional status ${ }^{(14)}$.

The high rate of initiation of complementary feeding at the recommended time (6 months) in this study relates to the frequency of visits parents to neighborhood health center is $93.7 \%$ and through statistical tests are statistically significant association $(\mathrm{P}=0.002)$. The support was given the study of community-based health centers where activities related to the health of children is mostly done in the neighborhood health center. Various efforts have been taken by the government to deal with issues related to the provision of complementary feeding, one of the efforts made at this time is through cadres in maternal and child health centre $\operatorname{activities}^{(15)}$.

This study showed that $78.5 \%$ of respondents had never received counseling about feeding for infants and children. Through statistical tests about complementary feeding at first time related to the ever received counseling on infant feeding and child found a significant correlation $(\mathrm{P}=0.00)$. This result is supported by the mother's education level which $70.8 \%$ have $0-9$ years or a maximum of only completed primary education. Victor et al., (2012) stated that the factors causing inappropriate the provision of complementary foods are low levels of maternal education and limited access to mass media ${ }^{(11)}$. For variable on the number of family members associated with the provision of complementary foods at first time appear to be associated $(\mathrm{p}=$ 0.005). There are $79.3 \%$ of families who membered 1-4 person providing complementary foods at the suggested time that the age of 6 months onward. In contrast to variable of maternal age, mother's education and father, mother and father work, gender, number of children and socio-economic of family had no relationship to complementary feeding at first time.

Despite statistically seems no relationship, mother's occupation in particular tend to have a a relationship to the provision of timely complementary feeding. As a housewife make them to provide complementary foods at the recommended time $(77.8 \%)$. The research was supported by (Chapagain, 2013) that the mother's occupation as housewife is closely linked to the proper feeding practices ${ }^{(12)}$. 


\section{CONCLUSION}

Community in South Central Timor, East Nusa Tenggara Province largely been doing complementary feeding first time suggested at the time (age 6 months) and the type of complementary foods given are mostly instant porridge. Factors significantly associated with the provision of complementary foods are routinely brought the child to the neighborhood health center and never got counseling for child feeding and number of household members. therefore, it is crucial to increase the educational activities for improving complementary feeding practices.

\section{REFERENCES}

1. World Health Organization. Strengthening action to improve feeding of infants and young children 6-23 months of age in nutrition and child health programmes. Report of proceedings; 2008. p. 6-9.

2. Wang, R. J., Trehan, I., Lagrone, L. N., Weisz, A. J., Thakwalakwa, C. M., Maleta, K. M. \& Manary, M. J. Investigation of food acceptability and feeding practices for lipid nutrient supplements and blended flours used to treat moderate malnutrition. Journal of nutrition education and behavior. 2013:258-263.

3. World Health Organization. Global strategy for infant and young child feeding. Geneva: WHO; 2003. WHOWHA55/2002/REC/1Annex 2; 2006.

4. Kapur, D., Sharma, S. \& Agarwal, K. N. Dietary intake and growth pattern of children 9-36 months of age in an urban slum in Delhi. Indian Pediatr. 2005:351-356.

5. Rao S, Swathi P, Unnikrishnan B, Hegde A. Study of complementary feeding practices among mothers of children aged six months to two years-A study from coastal south India. The Australasian medical journal. 2011.

6. Unicef. UNICEF For Children. Unicef Indonesia Laporan tahun 2012. Indonesia: Unicef; 2012.

7. Aggarwal A, Verma S, Faridi M. Complementary feeding-Reasons for inappropriateness in timing, quantity and consistency. The Indian Journal of Pediatrics; 2008. p. 49-53.

8. Flax VL, Phuka J, Cheung YB, Ashorn U, Maleta K, Ashorn P. Feeding patterns and behaviors during home supplementation of underweight Malawian children with lipid-based nutrient supplements or corn-soy blend. Appetite; 2010. p. 504-511.

9. Wojcicki JM, Gugig R, Tran C, Kathiravan S, Holbrook K, Heyman MB. Early exclusive breastfeeding and maternal attitudes towards infant feeding in a population of new mothers in San Francisco, California. Breastfeeding medicine. 2010:9-1.

10. Joshi N, Agho KE, Dibley MJ, Senarath U, Tiwari K. Determinants of inappropriate complementary feeding practices in young children in Nepal: secondary data analysis of Demographic and Health Survey 2006. Maternal \& child nutrition. 2012:45-59.

11. Victor R, Baines SK, Agho KE, Dibley MJ. Factors associated with inappropriate complementary feeding practices among children aged 6-23 months in Tanzania. Maternal \& child nutrition. 2012.

12. Chapagain RH. Factors affecting complementary feeding practices of Nepali mothers for 6 months to 24 months children. J Nepal Health Res Counc. 2013.

13. Sethi MV, Kashyap S, Seth V. Effect of nutrition education of mothers on infant feeding practices. The Indian journal of pediatrics. 2003:463-466.

14. Adokiya MN. Complementary feeding practices and nutrition status of young children 06-23 months of age in the Kassena-Nankana District, Upper East Region, Ghana. Kwame Nkrumah University of Science And Technology. 2010.

15. Ellis CMK, Khomsan A, Sukandar D, Atmawikarta A. Nutritional Education Intervention for children under five years' mother and cadre of Integrated Service Center Post (Posyandu) in increasing skill and behaviour knowledge (PSK) and nutritional status of children under five years old (Balita); 2010. 